\title{
Tourism Taxation, Politics and Territorialisation in Tanzania's Wildlife Management
}

\author{
Emmanuel Sulle ${ }^{a, \#}$ and Holti Banka ${ }^{b}$ \\ anstitute for Poverty, Land and Agrarian Studies (PLAAS), University of the Western Cape, South Africa

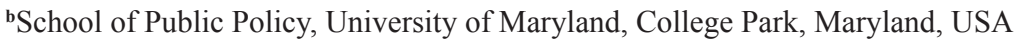

\#Corresponding author. E-mail: esulle@plaas.org.za

\begin{abstract}
Tourism activities occurring on communal lands such as Wildlife Management Areas (WMAs) are increasing in Tanzania. This is the result of natural resources governance reforms aimed to empower communities to manage and benefit directly from resources found in their jurisdictions. This article explores the impacts of taxes imposed on tourism activities occurring on communal lands and the emerging politics of resource and revenue sharing among WMA member villages. In the process, we use empirical data gathered from two WMAs in northern Tanzania between 2006 and 2016. We find that while the current high tax rates on tourism businesses occurring at the grassroots level reduce revenue earned by communities, the main challenge facing the studied WMAs is the model of revenue sharing among WMA member villages. Currently, as the result of WMA regulations, villages which had prior arrangement with tour operators in their land have suffered revenue losses as they have to share revenue equally with other members of the WMA. We argue that the current tax regime coupled with the contested cost and benefit sharing model not only lower returns to grassroots communities--which in turn discourage their much needed participation in conservation-tourism initiatives--but also generate new forms of struggles over resource control.
\end{abstract}

Keywords: community-based conservation, wildlife, WMA, tourism taxation, decentralisation, Tanzania

\section{INTRODUCTION}

Following the natural resources governance reforms aimed to empower communities to manage and benefit directly from resources found in their jurisdictions (URT 1998; Nelson et al 2006; Snyder and Sulle 2011), tourism activities occurring in communal lands such 'Wildlife Management Areas' (WMA) are on the increase in Tanzania. Using the cases of Burunge and Randilen WMAs, this article explores the implications of taxes imposed on tourism activities occurring in communal

\begin{tabular}{|l|l|}
\hline \multicolumn{2}{|c|}{ Access this article online } \\
\hline Quick Response Code: & Website: \\
\hline & www.conservationandsociety.org \\
\cline { 2 - 3 } & \\
& \\
&
\end{tabular}

lands and the politics of resource and revenue sharing among WMA member villages. It seeks to unpack such implications on cost and revenue distribution between the WMA member villages and the central government on the one hand, and on communities' participation in conservation-tourism initiatives on the other.

Given the risks of corruption and inefficiencies with respect to taxes, and the lack of accountability and poor service delivery at the central level, a number of studies have claimed that enabling local communities with powers to collect and maintain revenues generated from natural resources is critical (Larson 2003; Ribot 2003; Lund 2007). This call to enable local communities to manage revenue has, however, been criticised on the grounds that the system at the lower level is neither fully democratic nor efficient (Brockington 2008). Brockington (2008) thus suggests that until the local government authorities develop efficient institutions that avoid the use of coercive and abusive means of tax collection, effective decentralisation of tax collection is unlikely to materialise.

Copyright: (c) Sulle and Banka 2017. This is an open access article distributed under the terms of the Creative Commons Attribution License, which permits unrestricted use and distribution of the article, provided the original work is cited. Published by Wolters Kluwer - Medknow, Mumbai | Managed by the Ashoka Trust for Research in Ecology and the Environment (ATREE), Bangalore. For reprints contact: reprints@medknow.com 
In Tanzania research has documented cases of elites' capture of revenues from the tourism sector (Sachedina 2008; Cooksey and Kelsall 2011; Nelson 2011). Others provide analyses of WMAs in the north (Goldman 2003; Nelson et al 2006; Igoe and Croucher 2007; Sulle et al 2011; Benjaminsen et al 2013; Bluwstein et al 2016), the village-operator initiatives in a number of villages in northern Tanzania (Nelson 2004; Nelson and Makko 2005; Sulle 2008; Snyder and Sulle et al 2014) and WMAs performance in Tanzania at large (USAID 2013; PIMA 2015).

However, there is no study which provides a nuanced and empirically grounded analysis of the current tax system, revenue sharing model, and the multiple regulations imposed on tourism activities occurring in the communal lands. This study fills this gap. It does so by assessing the political economy of Tanzania which continues to shape the performance of community-based conservation and tourism initiatives. It focuses on WMAs, and uses its analysis to make recommendations on best practices in the tourism sector in the communal lands in ways that allow local communities to retain more revenues from conservation-tourism activities.

Moreover, the paper examines incentives to build up the communal conservation and tourism industry in Tanzania. By doing so, we do not endorse the argument that too many taxes (i.e. big government and state interference) are bad for the economy, but rather illustrate that the current tax rates compounded with the lack of transparency within the state institutions hinder the development of sustainable conservation and tourism initiatives at the grassroots level (Agrawal and Ribot 1999; Nelson and Agrawal 2008; Benjaminsen et al 2013). We argue that an effective model of cost and benefit sharing among and between the core actors within the WMA is lacking in the current debates on the governance, management and administration of wildlife at the community level.

Presently, as we elaborate below, two distinct tax regimes are at play for the tourism activities occurring in the communal lands that include village lands and the WMAs. The central government collects 60 percent and 35 percent of total revenue generated from tourism activities occurring in village lands and WMAs respectively (Sulle et al 2011, 2014).

We use empirical data gathered by the first author on community-based conservation and tourism initiatives in northern Tanzania between 2006 and 2016. Primary data on tourism revenue and expenditure was gathered from Burunge WMA for several years (Nelson, Sulle and Ndoipo 2006; Sulle 2008; Sulle et al 2011; Snyder and Sulle 2011; Sulle, Banka, and Ntwaliwa 2014). We use secondary data to build our theoretical framework and develop policy recommendations. For comparative purposes, the paper draws lessons from other countries, including communal conservancies in Namibia and Kenya. The rest of the paper is structured as follows: Section 2 provides an overview of the politics of wildlife conservation and tourism taxation while Section 3 takes a closer look at the situation in WMAs in terms of their performance, villagers' perceptions and emerging resistance among member villages. Section 4 discusses the findings as well as a number of actions that could potentially be adopted moving forward by the relevant stakeholders in the country. The article ends with concluding remarks which locate the article into the broader picture of evolving debates.

\section{THE POLITICS OF WILDLIFE CONSERVATION AND TOURISM TAXATION}

In Tanzania, as in many other African countries, wildlife tourism plays a central role in the overall tourism industry (UNWTO 2014). Following a significant decline of its wildlife populations, the government of Tanzania in collaboration with development partners, carried out major reforms in its wildlife sector in the late 1990s (WSRTF 1995; Nelson et al 2006, Nelson 2011). Major changes include the introduction of the first Wildlife Policy of Tanzania (WPT) of 1998 and implementation of structural adjustment programs (SAPs) (Nelson 2011; Benjaminsen et al. 2013). The policy reforms and subsequent interventions in the wildlife and tourism were geared towards improved conservation and increased participation of stakeholders in both conservation and tourism sectors (URT 2013). Among the key reforms contained in the wildlife policy of 1998 is the provision for the local communities to fully participate to conserve, manage, and benefit directly from wildlife and other resources found within their village or communal lands (URT 1998; Nelson and Blomley 2010).

This decentralisation was based on the premise that "policies that devolve control over resources to local communities are certainly a positive step for fairer distribution of the economic benefits flowing from those resources" (Snyder and Sulle 2011:4). Therefore, as a result of decentralisation of the wildlife governance, WMAs, which are areas of village land set aside for purposes of wildlife conservation (Nelson and Agrawal 2008), were established. The pilot WMAs were in place since the 1990s, however, the first 16 WMAs were only officially gazetted in 2006.

Currently 22 WMAs in total have received their authorised association $^{1}$ status and user rights $^{2}$, while 16 more WMAs are in various stages of development in different parts of the country.

WMAs and villages generate their income from concession fees paid by investors who enter three year contractual arrangements with them to establish campsites and lodges among other facilities within WMAs and village lands. Other activities carried out in these areas include tourists' camping and game viewing.

As a result of these reforms, foreign investment in the wildlife tourism has increased significantly (Benjaminsen et al. 2013; URT 2012), making tourism the main earning sector of foreign currency in the country. In 2014, tourism contributed about 25 percent of total foreign currency to the national coffers. Income from tourism services rose from USD 400 million in 1998 to about USD 2 billion in 2014 (Ndulu 2015:3). To date, the nation has about 40 percent of its land under different categories of protection (Benjaminsen et al 2011). However, the existing investments in communal lands are yet to bring any significant changes in community-based 
conservation initiatives. This is largely due to the fact that the the Tanzanian central government still maintains control over such resources (Benjaminsen et al 2013).

This situation contrasts with some other African countries, such as Namibia and Kenya which have fully decentralised wildlife governance in community conservancies to rural communities governance (Naidoo et al 2016; Nelson et al 2016). These reforms presently allow communities in both Namibia and Kenya to retain 100 percent of revenues generated from both photographic and hunting tourism (Nelson et al 2016:3). Environmentally, the reforms are showing positive results as the number of wildlife population is on the increase in communal conservancies in both countries (Nelson et al 2016). Although challenges of power asymmetries between communities and conservation tourism entrepreneurs persist (Sullivan 2005, 2006; Hoole 2010; Lapeyre 2011; Silva and Motzer 2014), studies link the success among the Namibian communities to long-term partnership between communities and the national and international conservation and rural development organisations (Jones 2012; Nelson et al 2016).

In Tanzania in contrast, as we elaborate below, communities retain only about 60 percent of total revenue from both hunting and photographic tourism revenues (Nelson et al 2016), due to high levels of taxes on tourism occurring in communal lands coupled with low investments. This impedes local conservation and development outcomes (Sulle et al 2011; Nelson et al 2016). As we explain, the main concern lies not only with the amounts of taxes and levies payable, but also with the complicated regime which encourages non-compliance and conflicts between investors and communities on the one hand, and communities and state authorities on the other.

It is important to note that before the introduction of WMA in mid 2000s a number of villages adjacent to protected areas such as national parks had long established conservation and tourism initiatives in partnership with tour operators (see Nelson 2004; Nelson and Makko 2005; Sulle 2008; Snyder and Sulle 2011). Tourism initiatives practiced in communal lands include establishments such as camping sites, tented lodges, and game drives.

\section{Revenue and taxation regime on tourism businesses in communal lands}

Presently, both conservation and economic activities within WMAs are guided by the Wildlife Conservation (Non-consumptive Wildlife Utilisation) Regulations, 2008; the Hunting Regulations, 2010; and Wildlife Conservation (Wildlife Management Areas) Regulations, 2012. Further, the Wildlife Conservation (Tourist Hunting) Regulations, 2010 and Wildlife Conservation (Resident Hunting) Regulations, 2010; both provide for the division of revenues generated from tourist and resident hunting between the Wildlife Division, Tanzania Wildlife Protection Fund (TWPF) Treasury, District Council and the WMA (see Table 1).

The introduction of all these regulations radically changed the operations of WMAs and their existing relationship with
Table 1

Sharing of income generated from tourist hunting activities in the WMA

\begin{tabular}{|l|l|c|c|c|c|}
\hline S/No & Fee's type & TWPF & WMA & $\begin{array}{c}\text { District } \\
\text { council }\end{array}$ & Treasury \\
\hline 1 & Block fee & $25 \%$ & $75 \%$ & 0 & 0 \\
\hline 2 & Game fee & $25 \%$ & $45 \%$ & $15 \%$ & $15 \%$ \\
\hline 3 & Conservation fee & $25 \%$ & $45 \%$ & 0 & $30 \%$ \\
\hline 4 & Observers fee & $25 \%$ & $45 \%$ & 0 & $30 \%$ \\
\hline 5 & Permit fee & $25 \%$ & $15 \%$ & 0 & $60 \%$ \\
\hline
\end{tabular}

Source: URT (2012) WMAs Regulations; pp. 65

investors and their member villages because they mandated only the Wildlife Division to collect and distribute all revenues generated in both WMAs and village lands. Fees and taxes differ according to the form of tourism. The Wildlife Division returns 65 percent of the total revenue generated from non-consumptive (photographic) tourism in a respective WMA to that WMA. However WMAs are used for hunting, which have a variety of taxes divided in several ways as shown in Table 1.

Moreover, the WMA regulations stipulate the allocation of total revenue earned by each WMA as follows:

- No less than 15 percent shall be re-invested for resource development;

- $\quad$ No less than 50 percent shall be directed to member villages forming the WMA;

- $\quad$ No less than 25 percent shall be used to strengthen the Authorized Association (AA).

Since 2010, after the implementation of these new regulations a number of village - tour operator initiatives have either collapsed or their businesses have suffered (see Sulle et al 2014). Indeed, the implementation of the 2007 Wildlife Policy and the subsequent non-consumptive Wildlife Utilization Regulations of 2008 have, to a large extent, reduced villages' expectations of generating significant revenues from the country's growing tourism industry. We illustrate this using the two case studies of Burunge and Randelin WMAs.

\section{THE CASE STUDIES}

\section{Case Study One: Burunge WMA}

Burunge WMA was among the first four WMAs established in the country, gazetted and received its user rights in 2006. It comprises 10 villages and lies in a wildlife rich corridor that connects the Tarangire National Park and Lake Manyara National Park (Sulle and Nelson 2011). This area is well-known for its large herds of elephants and buffalos that move in and out of Tarangire. The WMA is the home of Lake Burunge, which hosts a diversity of migratory water birds such as greater and lesser flamingos, and a range of ducks and shorebirds (Nelson et al 2006).

The WMA has one of the most wildlife rich hunting blocks in the Burunge Game Controlled Area. Since its establishment, Burunge WMA has seen the development of five lodges and one campsite in its vicinity. It has recorded a significant 
increase in revenue and in kind contribution, both from conservation and development agencies, and also from tour operators. Its revenue increased from a mere USD 30,141 in 2006-2007 to USD 449,338.50 in 2014-2015 (see Figure 1).

In 2010, Burunge WMA earned around USD 157,000 as part of the 65 percent designated WMA revenue from photographic tourism (Burunge WMA 2011; Sulle and Nelson 2012). As we illustrate below, one of the ten member villages never accepted its revenue share from the WMA, but the rest of the villages received around USD 8,000 each as part of the 50 percent gross income earned by the WMA. Indeed, if the government did not charge a 35 percent tax on the gross income, each village would have earned approximately USD 12,000 in 2010 (Sulle and Nelson 2012). Based on this formula, in 2014/2015 each member village netted a total of USD 22,466 as its share of revenue from the WMA.

WMA member villages use their share of revenue distributed by the WMA to pay for the provision of social services. In Burunge WMA, for instance (as shown in Figure 2), 62 percent of such revenue was reinvested into building schools; 27 percent was used to pay secondary school students tuition fees; the remaining 11 percent was used for other projects related to water and building village offices (HDIC 2010).

While these revenues are welcome, in other respects WMA should be viewed as a form of state regulation and control that impedes the provision of local benefits. This is illustrated by a number of villages which had prior investment agreements with investors in their lands that resisted joining the WMA due to fear of losing their revenues. Since the establishment of the Burunge WMA, Vilima Vitatu Village has maintained its private contract with the investor (Tarangire River Camp) which is technically in the WMA area, and thus, supposed to have an agreement with the WMA instead of an individual village. For this reason, this village receives income from both the WMA and the individual investors. For instance, during the financial year 2008-2009, it earned USD 2,971 from the WMA, and USD 16,435 from the Tarangire River Camp (Table 2). As these numbers clearly illustrate, there is no incentive for

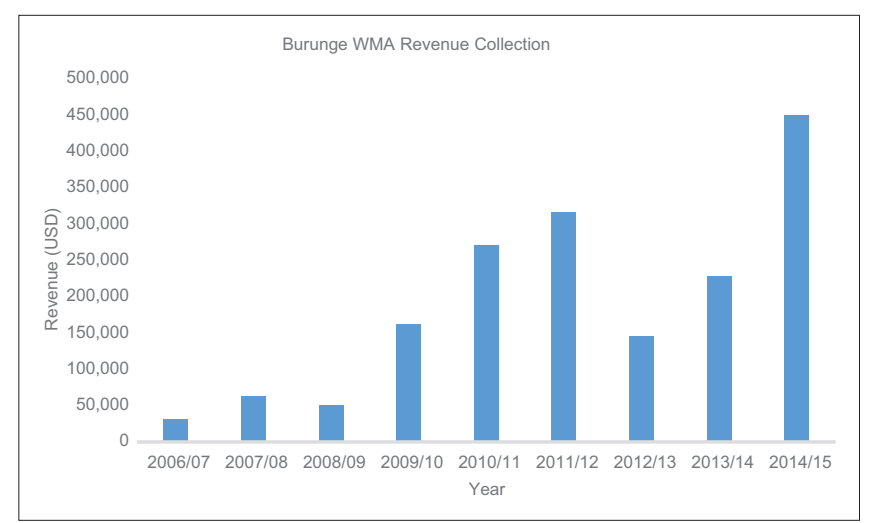

Figure 1

Burunge WMA revenue from photographic and hunting tourism 2006 - 2015. Source: Burunge WMA unpublished reports, obtained by authors, October 2016 a village that has had a contract with the investor before the establishment of the WMA to abandon its fortune. The WMA framework requires villages that are part of it to share revenues earned annually. This strategy reduces the amount that each village receives from the WMA. The amount has become even smaller due to the current wildlife revenue distribution described above.

Minjingu is another village which has protested its inclusion in the WMA from the first day the WMA was gazetted in 2006. The village has since then claimed that there was inadequate consultation and forgeries of minutes of village meetings during the establishment of the Burunge WMA (Nelson et al 2006; Igoe and Croucher 2007; Bluwstein 2016). This is because the village has had a joint venture with Kibo Tours - the company which established a tourist lodge - Maramboi Tented Lodge in its land before the establishment of the WMA (Nelson et al 2006). It had allocated 40 acres of its land at Maramboi area for the tour operator to construct the lodge and paid it USD 5 per day for each guest it accommodated. Using its earnings from the investor, the village had implemented a number of investments in social services including secondary school buildings and the village office (Sulle 2008). The Maramboi Tented Lodge, however, ceased to comply with that contract in 2008 on grounds that it was ordered to pay USD 15 bed night fee to the WMA. However, as a result of its decision to reject the WMA, Minjingu Village was not paid by the WMA, and the district officials have made it clear that the village will only receive its WMA share when it becomes part of the WMA(HDIC 2010; Sulle et al 2011). This therefore, represents another case of government regulations impeding a locally agreed arrangement.

In retaliation, in 2014 the Minjingu Village Council filed a land case at the High Court of Tanzania, against Maramboi Tented Lodge and the Burunge WMA Registered Trustees. In its case, the Village Council argued that the WMA did not fall in its area of jurisdiction as the 2005 regulations guiding

Table 2

Vilima Vitatu income from WMA and Tarangire River Camp (TRC)

\begin{tabular}{|l|c|c|}
\hline Year & WMA (USD) & TRC (USD) \\
\hline $2007-2008$ & - & 13,902 \\
\hline $2008-2009$ & 2,971 & 16,435 \\
\hline $2009-2010$ & 5,300 & - \\
\hline
\end{tabular}

Source: HDIC 2010; Sulle and Nelson 2012

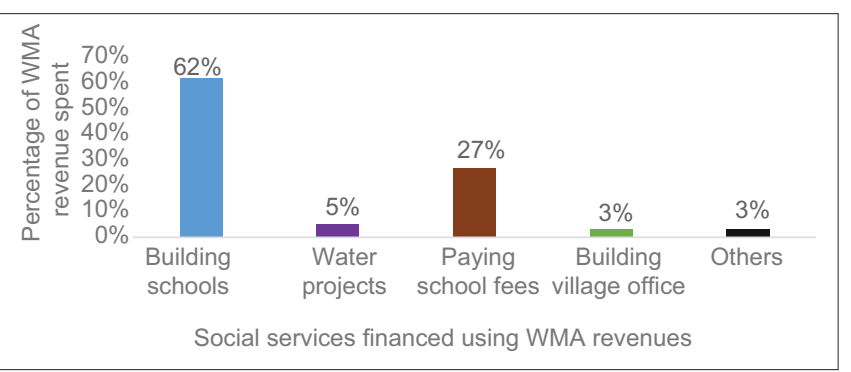

Figure 2

Expenditure patterns of tourism revenue in Burunge WMA. Source: Authors'fieldwork, HDIC 2010 
the formation of the same (WMA) were not followed. The Village Council accused the WMA of forcefully occupying, managing, and using the land it allocated for pastoralism and village forests while knowing the village had not opted to join the WMA yet.

After two years of court battle, in 2016, the court found the Maramboi Tented Lodge not guilty of breaching its contract with the village council. The court, however, found the WMA guilty of trespassing into the Minjingu village's land, ordering it to pay USD 746,114 compensation.

While the WMA has appealed against this court ruling and the matter remains a court issue, the problem of discontent with the WMA is also growing among other members of the WMA. During the field visits in 2011, it was established that farmers in Manyara village had cultivated in a designated WMA area and the village authorities had reportedly failed to take them off this land. As a result, the WMA has cut off its due share of revenue from the WMA annual income (Sulle et al 2011). This situation has reportedly remained the same till date (Bluwstein et al 2016). During the same study time (2011), the leaders of Vilima Vitatu Village were in favor of maintaining the two contracts they had entered, with the investor and the WMA. The leaders claim that their village has a larger area in the WMA, and therefore, deserves a higher pay than the other villages in the WMA. Understanding the core causes of village members' dissatisfaction with the WMA and their forms of resistance are critical in determing villagers' participation in conservation initiatives and the sustainability of WMAs at large.

\section{Case Study Two: Randilen WMA}

Officially gazetted in 2012, Randilen WMA is among the most recently established WMAs in the country. It is located in Monduli District, Arusha Region and it was granted its user right by the Wildlife Division Director in 2013. With a total area of 31,200 hectares and eight villages, the WMA forms an important part of the ecosystem often used by about 1,000 elephants migrating from and between the Tarangire National Park, Manyara Ranch and Manyara National Park (NTRI 2016).

Due to its strategic location, next to Tarangire National Park, the WMA offers potential sites for investments in tourism facilities such as lodges, hotels, and camp sites. However, at present the WMA has only a single income-generating investment owned by Elewana - the Tree Top Lodge established in Lolkisale Village before the WMA was established. There is no hunting activity reported by the WMA leaders interviewed during the course of this study.

Since this WMA is still new, it is difficult to assess its performance more broadly. Nonetheless, it is critical to highlight the present and past experiences of Lolkisale Village after the two wildlife regulations (Non-consumptive Wildlife Utilisation Regulations of 2008 and the WMA regulations of 2012) were implemented. This is because officially, at present, all revenue generated in the Randilen is collected, managed, and distributed by its authorised association. The present WMA regulations of 2012 require each WMA member village to receive an equal share of the total revenue generated by the WMA regardless of its share of land in the WMA. On the basis of equal sharing among members of the WMA the present revenue model undermines villages which have given much of their land and have established long-term relationships with investors. Lolkisale Village is one of the villages which has established for over a decade joint ventures with private tour operators in its land. But, to-date, after it joined Randilen WMA and despite offering much of its land to the WMA including areas in which the tourist lodges have been established, the village receives the same share as the other seven villages which form the Randelin WMA.

As a result of the new arrangement under the WMA revenue sharing model, Lolkisale Village lost a significant amount of the revenue it used to get from its previous arrangement with tour operators. For instance, in 2009 Lolkisale earned about USD 95,003, and it could have earned a total of USD 156,966 in 2012 (Figure 3). However, since 2010, when the investor (Elewana) started to follow the Ministerial directives to pay all the fees and charges to the Wildlife Division, the village's earnings dropped to the tune of USD 5,304 per year (Figure 3). In practical terms, the present earnings by Lolkisale Village are nearly 18 times less than what the village earned back in 2009.

Villagers are becoming aware of the revenue shortages, because the village government demands more contribution from them to pay for the construction of new primary and secondary schools. In the past, most of these activities were paid off using the revenue earned from tour operators who were used to paying directly to the village's bank account. It is thus likely that this situation will in turn disincentivise villagers who were starting to enjoy tangible benefits from their conservation efforts.

\section{DISCUSSION}

The two cases of Burunge and Randilen WMA at first demonstrate two similar issues. On the one hand, the overall incomes earned by each WMA has increased from the time they were established while, on the other hand, they show growing discontent among the WMA member villages, particularly, among villages which have had their own arrangements with

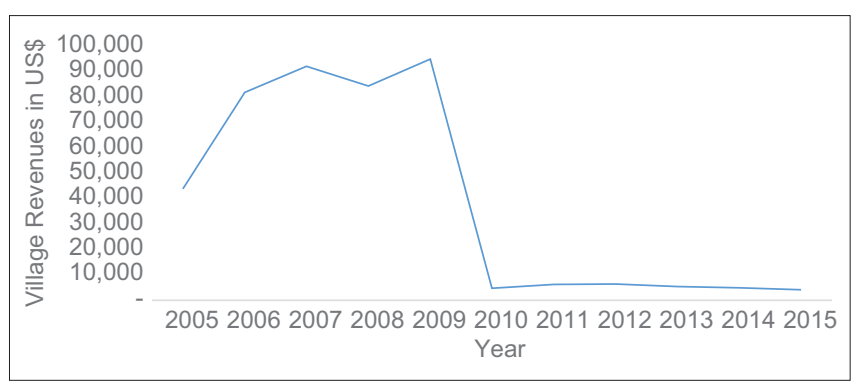

Figure 3

Tourism revenue received by Lolkisale Village before and after the current revenue and taxation regime was enforced. Sources: Authors collection from the investor in Randilen WMA; WMA office; NTRI 2016 
investors. The fact that some of the villages have never earned significant income as a share of revenue from the WMA cannot be overlooked. This is because such revenues are used for the provision of key social services such as the construction of classrooms, teachers' houses, village offices, or water supplies (HDIC 2010; Sulle et al 2011). Yet, those villages which established joint ventures with tour operators will, in fact, under the current tax and regulatory regime register lower income from the WMA, and hence, fail to meet their targets. These targets include the provision of the same services as above to their village members.

This brings us to a fundamental issue which is lacking in the current debates on the governance, management, and administration of wildlife at the community level: the model of cost and benefit sharing among and between the core actors. As we have shown, most of the existing literature has tackled the revenue distribution issue, particularly, the existing model in which each member village of the WMA receives an equal share of WMA proceeds (Nelson et al 2006; Benjaminsen et al 2013; USAID 2013; Sulle et al 2014; Bluwstein et al 2016). However, this model seems to be unsustainable, and it is likely to exacerbate conflicts between WMA member villages, mostly those which have allocated more land to WMAs and the WMA authority (Sulle et al 2011; Sulle and Nelson 2012; Bluwstein et al 2016). Although, the government and most of the facilitating organisations in the northern zone downplayed this problem, it is crucial to understand that communities in villages which have given much of their land to the WMA are bearing the opportunity cost of allocating such land to the WMA and further to investors who use such lands for construction of lodges, hotels, and/or campsites. Hence, a need for a new model has emerged, which ensures that costs and benefits are shared by each member village of the WMA. A possible alternative model is the one that bases payments for member villages of the WMA on a pro rata basis of the amount of land each village has contributed to the WMA. For WMAs to implement this alternative arrangement and function in this new form of territorialisation (Igoe and Brockington 2007), they need new forms of political sensibility and collective self-awareness among their member villages, otherwise, they will remain a group of disparate and conflicting villages.

Yet, while the alternative model we propose may reduce existing conflicts between villages and the WMA, the existing taxation on revenues generated from tourism activities occurring in communal lands needs to be viewed as part of the bigger issue - the government continuing interventions on community-based conservation and tourism initiatives. It should be noted that the present taxes levied on local communities (35 percent of total revenue from non-consumptive tourism) are higher than those charged on a wealthy state entity responsible for the overall governance, protection, and administration of all parks in the country - the Tanzania National Park Authority (TANAPA). TANAPA pays a corporate tax that is 30 percent of its net profit and 15 percent of total revenue to the Treasury (contribution to the government), and three percent of total revenue to tourism development fund (TANAPA 2013; NTRI 2016). This comparison serves to show that reducing taxes on community managed initiatives is viable and desirable for the benefit of these communities and the nation at large.

By retaining sufficient revenues, local communities are encouraged to participate fully in, and gain substantially from their conservation efforts. Indeed, economically, the government would not lose much of its revenues by leaving revenues earned in the communal lands to those particular communities because they would be invested in needed social services as indicated above. Practically, therefore, the establishment of these service provision sectors would result in job creation at the local and national level. The employees would automatically be paying income taxes to the central government.

Indeed, this was part of the agreement between the government and development partners in the late 1990s, amidst the realisation of rampant poaching incidences and decline of wildlife (Nelson et al 2006). Unfortunately, this concept is not yet fully implemented. The Wildlife Policy of 1998 had some community friendly sections. However, those sections were left out in the 2007 Wildlife Policy that later formed the basis for the Wildlife and Conservation Act of 2009 (Benjaminsen et al 2013). As a result of the current policy constraints, local communities are no longer receiving direct payments from investors, but rather a percentage from the Wildlife Division. As other studies have also established, most of the revenue returned to WMAs are not clearly described in detail, making it difficult for WMA officials to understand how much the Wildlife Division has earned from all businesses under their jurisdiction (Sulle et al 2011; Bluwstein et al 2016). Yet, the amounts earned from tourism activities in the WMA remain insignificant compared to the income communities could earn from other economic activities such as farming (TNRF 2007). The current policy regime thus acts as a disincentive to local governments to control investments in their village lands. Efforts to improve the local communities' well-being, though, do not end with reduced tax rates and new revenue sharing models. They rather require that local communities acquire proper local tenure over resources, basic hospitality, and entrepreneurial skills (Ashley and Mitchell 2005; Snyder and Sulle 2011). Moreover, WMA leaders further need capacity building to improve their accounting skills, financial management, and reporting of the WMA revenues to wider communities including the WMA constituency. The civil society organisations are likely to play a crucial role in this regard.

\section{CONCLUSION}

In this paper, we revealed that while in general, the WMAs in the north have generated significant income to-date compared to their inception stage, not much of such benefits are reaching local communities. Yet, the impacts of such little revenue are felt differently among member villages of the WMA. Villages that have not allocated much of their land to the WMA, and have never had a tourism arrangement before the WMA are 
slightly happier than those who have allocated much of their land to the WMA with the latter losing out substantial income they used to earn from their previous arrangements with investors before the establishment of the WMA. We have shown that the current model of cost and revenue sharing among the WMA member villages is contested and the politics around prior arrangements between certain WMA member villages and tour operators need attention. Although the issue of high tax rates and unequal cost and benefit sharing do apply to the rest of the WMAs in the country (Benjaminsen et al 2013; Noe et al 2015), we argue that each WMA needs to be assessed separately based on nuances related to geographical location, socioeconomic, and political context, as these three factors determine the complexity of the issue.

We have shown how by imposing its intervention measures - complex regulations and higher rates of taxation on tourism activities occurring in the communal lands, the government disincentivises the participation of local communities in conservation tourism initiatives. It limits the ability of local communities to establish their own system of charges for tourism activities occurring within their own communal lands.

Instead, the government needs to design and implement policies that build on the participation of local communities as it has earlier indicated in the Wildlife Policy of 1998. As Snyder and Sulle (2011) have argued, "policies that devolve control over resources to local communities are certainly a positive step for fairer distribution of the economic benefits flowing from those resources" (2011:14). In this paper, we argue alongside other studies (Nelson 2004; Sulle 2008; Sulle et al 2011; Nelson et al 2016; NTRI 2016) that sustainable management of wildlife resources in the communal lands is achievable when communities earn tangible benefits directly from initiatives such as WMAs. This has been the central argument in the government efforts to decentralise the wildlife sector because tourism earnings at the local level provide income to the poor communities and thus help alleviate poverty. In principle, though, as we have demonstrated, there is little benefit to communities when the central government still controls revenues from tourism activities occurring in communal lands and charges them high rates of taxes while little intervention is made to address problems associated with the prior arrangements between WMA member villages and tour operators. We argue that establishing a payment mechanism that bases payments for WMA member villages on a pro rata basis of the amount of resources (such as land) each village has contributed to the WMA could be a step forward.

As we have shown, experience from other parts of Africa indicate that community-based conservation and tourism initiatives are possible and their success largely depends on the extent to which the government has devolved powers to own, manage and administer such initiatives. By providing this empirically grounded study, we believe the article contributes towards a more nuanced understanding of the impacts of taxation on community-based conservation and tourism initiatives, evolving debate on cost and benefit-sharing and the devolution of natural resource (wildlife) management. We emphasise that the participation of rural communities in the conservation and tourism initiatives is critical and this can be sustained if these communities earn substantial income from them. The current tax regime coupled with other natural resource governance problems identified in this paper threaten this possibility.

\section{ACKNOWLEDGMENTS}

We would like to express our heartfelt gratitude to Robert Nelson, Christine Noe, Fred Nelson, Alicia Davis, Daniel Brockington - the editor and two anonymous reviewers for their constructive and inspiring comments on the earlier drafts of this article. Additional comments were received at the editor and junior writers' workshop organized by Daniel Brockington and sponsored by the British African Studies Association. School of Public Policy at the University of Maryland College Park, Sand County Foundation, Tanzania Natural Resource Forum, and Maliasili Initiatives funded Sulle's earlier research projects which informed this paper. We thank Sirili Akko and Mike Sanders for providing enormous data on tourism businesses. We are also grateful to all people that E. Sulle interviewed during his field works in rural Tanzania between 2006 and 2016.

\section{NOTES}

1. The WMA regulations, 2012 describe authorised association as a community based organization, whose primary objective is to conserve wildlife resources for the benefit of local community members ordinarily residing in that particular area.

2. User right is the official permission granted by the Director of Wildlife to an authorised association to utilise wildlife resources in the Wildlife Management Area in accordance with the WMA Regulations, 2012.

\section{REFERENCES}

Agrawal, A. and J. Ribot. 1999. Accountability in decentralization: aframework with South Asian and West African Cases. Journal of Developing Areas 33: 473-562.

Ashley, C., \& J. Mitchell. 2005. Can tourism accelerate pro-poor growth in Africa? ODI Opinions: <http://www.odi.org.uk/publications/opinions 60>. London: Overseas Development Institute. Accessed on November 26, 2013.

Benjaminsen, T., I. Bryceson, F. Maganga, T. Refseth. 2011. Conservation and land grabbing in Tanzania. International Conference on Land Grabbing. Institute of Development Studies. University of Sussex, UK. 6-8 April 2011.

Benjaminsen, T., M. Goldman, Y. Minwary, and F. Maganga. 2013. Wildlife management in Tanzania: state control, rent seeking and community resistance. Development and Change 44(5): 1087-1109.

Bluwstein, J., F. Moyo, R. Kicheleri. 2016. Austere conservation: understanding conflicts over resource governance in Tanzanian wildlife management areas. Conservation and Society 14:218-31

Brockington, D. 2008. Corruption, taxation and natural resource management in Tanzania. Journal of Development Studies 44(1):103-26

Cooksey, B., and T. Kelsall. 2011. The political economy of the investment climate in Tanzania. London: Africa Power and Politics Programme.

Gardner, B. 2012. Tourism and the politics of the global land grab in Tanzania: 
markets, appropriation and recognition. Journal of Peasant Studies 39(3): 377-402.

Goldman, M. 2003. Partitioned nature, Privileged knowledge: community-based conservation in Tanzania. Development and Change 34 (5): 833-862.

HDIC (Health and Development International Consultants). 2010. SocioEconomic baseline studies in selected WMAs under the financial crisis initiative/cash-for-work program. Report prepared for WWF - USAID fund.

Hoole, A. (2010): Place - power - prognosis: community-based conservation, partnerships and ecotourism enterprise in Namibia. International Journal of the Commons Vol. 4: 78-99.

Igoe J, and D. Brockington. 2007. Neoliberal conservation: brief introduction. Conservation and Society 5:432-49

Igoe, J. and B. Croucher (2007) Conservation, commerce, and communities: the story of community-based WMAs in Tanzania's Northern Tourist Circuit. Conservation and Society, Vol. 5 (4) 534-561

Jones, B. 2012. The evolution of Namibia's communal conservancies. In: Nelson, F. Community rights, conservation and contested land: the politics of natural resource governance in Africa. Routledge, Oxford

Lapeyre, R. (2011) 'Governance structures and the distribution of tourism income in Namibian communal lands: anew institutional framework'. Tijdschrift voor Economische en Sociale Geografie 102(3): 302-15.

Lapeyre, R. 2010. Community-based tourism as a sustainable solution to maximise impacts locally? The Tsiseb conservancy case, Namibia. Development Southern Africa 27 (5): 757 - 772.

Larson A. 2003. Decentralisation and forest management in Latin America: towards a working model. Public Administration and Development 23: $211-226$.

Lund. J. 2007. Is small beautiful? village level taxation of natural resources in Tanzania. Public Administration and Development 27 (4): 307-318.

Naidoo, R., Weaver, L. C., Diggle, R. W., Matongo, G., Stuart-Hill, G. and Thouless, C. (2016), Complementary benefits of tourism and hunting to communal conservancies in Namibia. Conservation Biology Vol. 30 (3) 628-638.

Ndulu, N. 2015. The importance of economic transformation. (In: High level workshop on shaping economic transformation in Tanzania: challenges and potential solutions. Dar es Salaam: Keynote Speech at the Research on Poverty Alleviation Annual Workshop, Unpublished Report.

Nelson, F, E. Sulle and D. Roe. 2016. Saving Africa's vanishing wildlife: how civil society can help turn the tide. International Institute for Environment and Development (IIED). London: IIED. Brief.

Nelson, F. 2004. The evolution and impacts of community-based ecotourism in northern Tanzania. London: International Institute for Environment and Development. Issue paper no. 131.

Nelson, F. 2011. Blessing or curse? The political economy of tourism development in Tanzania. Journal of Sustainable Tourism 20(3): 359-375

Nelson, F. and A. Agrawal. 2008. Patronage or articipation? Community-based natural resource management reform in Sub-Saharan Africa. Development and Change 39(4): 557- 85.

Nelson, F. and S. Ole Makko. 2005. Communities, conservation, and conflict in the Tanzanian Serengeti. In: B. Child and M.W. Lyman (eds) Natural resources as community assets: lessons from two continents. Madison, WI: Sand County Foundation and the Aspen Institute. <http://www. sandcounty.net/assets/chapters/assets_chapter_5.pdf $>$. Accessed on September 23, 2014.

Nelson, F. Sulle, E. \& Ndoipo, P. 2006. WMAs in Tanzania, astatus report and interim evaluation. Tanzania Natural Resources Forum. August 2006.

Nelson, F., and T. Blomley. 2010. Peasants'forest and the king's game? Institutional divergence and convergence in Tanzania's forestry and wildlife sectors. In: F. Nelson (ed.) Community rights, conservation and contested land: the politics of natural resource governance in Africa (pp.
79-105). London: Earthscan.

Noe C, and R.Y Kangalawe. 2015. Wildlife protection, community participation in conservation, and (Dis) empowerment in Southern Tanzania. Conservation and Society 13:244-53.

NTRI (Northen Tanzania Rangelands Initiative). 2016. Making WMAs deliver for conservation and communities. Arusha, NTRI, $<$ http://www.ujamaacrt.org/uploads/1/2/5/7/12575135/ntri_brief_final.pdf $>$. Accessed on 27 April 2017.

PIMA (Poverty and ecosystem Impacts of Tanzania's Wildlife Management Areas). 2015. The economic and social viability of Tanzanian Wildlife Management Areas. University of Copenhagen, Department of Food and Resource Economics: Copenhagen. Brief.

Ribot JC. 2003. Democratic decentralisation of natural resources: institutional choice and discretionary power transfers in Sub-Saharan Africa. Public Administration and Development 23: 53-65.

Sachedina, H. 2008. Wildlife is our oil: conservation, livelihoods and NGOs in the Tarangire ecosystem, in Tanzania. $\mathrm{PhD}$ thesis. University of Oxford, Oxford, United Kingdom.

Silva, J. A. and N. Motzer. 2015. Hybrid uptakes of neoliberal conservation in Namibian Tourism-based development. Development and Change 46: 48-71

Snyder, K., \& E. Sulle. 2011. Tourism in Maasai communities: a chance to improve livelihoods? Journal of Sustainable Tourism 19(8): 935-951.

Sulle, E. 2008. Wildlife-based revenue transparency performance in Longido and Simanjiro Districts. HAKIKAZI CATALYST report. Retrieved from <http://www.hakikazi.org /papers/Wildlife-Base-Revenue.pdf $>$. Accessed on March 20, 2012.

Sulle, E. and F. Nelson. 2012. Community-based conservation in the Tarangire -Manyara Corridor: an assessment of existing models and experiences. Maasai Steppe Landscape Initiative, Arusha and Underhil, Tanzania Natural Resource Forum, and Maliasili Iniative. Study. Unpublished report.

Sulle, E. H., Banka and J. Ntalwila. 2014. Wildlife tourism experiences: case studies from rural Tanzania. In: Rural tourism: an international perspective (ed. Dashper, K.) Pp. 210-228. Newcastle: Cambridge Scholars Publishing.

Sulle, E., F., Nelson. and E. Lekaita. 2011. WMAs and Pastoralist Livelihoods: an assessment and analysis from Northern Tanzania, report for Tanzania Natural Resource Forum. Arusha, Tanzania Natural Resource Forum

Sullivan, S. (2005) 'Detail and dogma, data and discourse: food gathering by Damara herders and conservation in arid North-West Namibia' in K. Homewood (ed.) Rural Resources and Local Livelihoods in Africa pp. 63-99. New York: Macmillan Publishers.

Sullivan, S. (2006) 'Elephant in the room? problematising "New" (Neoliberal) Biodiversity Conservation'. Forum for Development Studies 33(1): 105-35.

Tanzania National Park Authority (TANAPA). 2013. Annual Report, Arusha, TANAPA.

Telfer, D. and R. Sharpley. 2008. Tourism and Development in the Developing World. London, Routledge.

TNRF (Tanzania Natural Resources Forum). 2007. Study on options for pastoralists to secure their livelihoods assessing the total economic value of pastoralism in Tanzania. Arusha, Tanzania Natural Resources Forum.

United Nations Word Trade Organisation (UNWTO). 2014. Towards measuring the economic value of wildlife watching tourism in Africa, UNWTO.http://apta.biz/wp-content/uploads/2014/10/UNWTOWildlife-Study_Report.pdf.Accessed on 24 December 2016. Briefing Paper.

URT (United Republic of Tanzania). 2012. The Wildlife Conservation (WMAs) Regulations 2012. Ministry of Natural Resources and Tourism, Wildlife Division, Government Printer: Dar es Salaam, United Republic of Tanzania.

URT. 1998. Wildlife Policy of Tanzania. Ministry of Natural Resources and 
Tourism. Government Printer: Dar es Salaam, United Republic of Tanzania.

URT. 1999. NationalTourism Policy 1999. Ministry of Natural Resource and Tourism. Government Printer: Dar es Salaam, United Republic of Tanzania.

URT. 2013. Tourism Statistical Bulletin. Ministry of Natural Resources and
Tourism: Dar Es Salaam, United Republic of Tanzania.

USAID. 2013. Tanzania WMA sevaluation: final evaluation report. USAID: Tanzania.

WSRTF (Wildlife Sector Review Task Force). 1995. A review of the wildlife sector in Tanzania Volume 1: assessment of the current situation. Ministry of Natural Resources and Environment: Dar es Salaam, Tanzania.

Received: May 2015; Accepted: July 2017

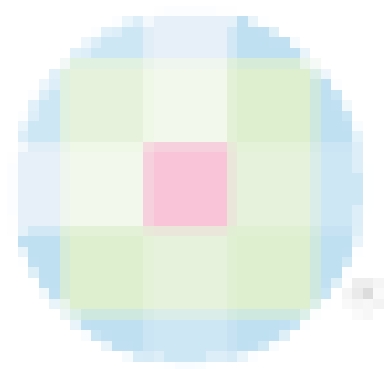

